\title{
Fertility Table Parameters of Predatory Bug Orius bifilarus Ghauri (Hemiptera: Anthocoridae) Preying upon Thrips palmi and Eggs of Corcyra cepholinica
}

\author{
Nisha Devi*, P.R. Gupta, K.C. Sharma, P.L. Sharma and B.R. Negi \\ Department of Entomology, College of Horticulture, Dr. Y.S. Parmar University of \\ Horticulture and Forestry, Nauni, Solan, Himachal Pradesh, 173 230, India \\ *Corresponding author
}

\begin{abstract}
A B S T R A C T
Keywords

Orius bifilarus,

Thripspalmi, Corcyra

cepholinica, Life table,

Age dependent

reprouction

Article Info

Accepted:

20 February 2018

Available Online:

10 March 2018

The study was carried out to construct the life table and to study the age dependent reproduction of the predatory bug Orius bifilarus feeding on fictitious host, eggs of rice meal moth, Corcyra cephalonica (Stainton) (Lepidoptera: Galleriidae) and on its natural host, Thripspalmi Karny (Thysanoptera: Thripidae) (collected from cucumber) under controlled conditions $\left(25 \pm 1^{\circ} \mathrm{C}, 65 \pm 5 \% \mathrm{RH}\right)$. Themean durations of the pre, post and oviposition periods were 4.3, 1.4 and 14.2 days on $C$. cephalonica eggs and 4.1, 2.1 and 16.4 days on thrips, the difference being non-significant. The fecundity of $O$. bifilarus reared on Corcyra eggs and thrips did not differ significantly and was 40.8 (20-65) eggs/female and 42.1 (7-67) eggs/female, respectively, though the female survival was slightly longer (22.7 days) on thrips as compared to Corcyra eggs (19.8 days). The intrinsic rate of natural increase $\left(\mathrm{r}_{\mathrm{m}}\right)$ on respective host was 0.088 and 0.085 and hence Corcyra eggs can effectively be used for mass rearing of $O$. bifilarus.
\end{abstract}

\section{Introduction}

Flower bugs in the genus Orius are efficient predators of a wide range of arthropod pests such as thrips, aphids, mites and eggs of lepidopteron pests (Wang et al., 2014). Although Orius spp. are polyphagous, these predators show a preference for attacking larval and adult thrips (Kakimoto et al., 2006; $\mathrm{Xu}$ and Enkegaard, 2009). Thrips (Thysanoptera) are cosmopolitan pests of manyimportant agricultural plants (Stuart et al., 2011). They cause damages directly by feeding and indirectly by transmitting viruses (Sakimura, 1963). Flower bugs have proven efficacious biological control agents against many thrips species, including Frankliniella occidentalis (Pergande) (Blaeser et al., 2004; Osekre et al., 2008; Chow et al., 2010), Frankliniella bispinosa (Morgan) (Shirk et al., 2012), Thripspalmi Karny (Kawai,1995; Carvalho et al., 2011; Hemerik and Yano, 2011) and Scirtothrips dorsalis Hood (Dogramaci et al., 2011). In India Orius indicus (Reuter), Orius insidiosus (Say), Orius tristicolor (White), Orius laevigatus (Fieber) and Orius albidipennis (Reuter), have been reported to be an effective predator of $F$. occidentalis, Therioaphis maculate (Buckton), Gynaikothrips ficorum (Marchal), 
Megalourothrips nigricornis, Sericothrips variabilis (Beach), eggs and newly hatched larvae of cotton bollworm, Helicoverpa armigera (Hübner) and Helicoverpa zea (Boddie), whiteflies, aphids, leaf hopper nymphs, mites and nymphs of cotton flea hopper, Psallus seriatus (Reut.) (Rajsekhara and Chatterji, 1970; Awadallah et al., 1977; Ananthakrishnan and Sureshkumar, 1985; Nasser and Abdurahiman, 2004).

Life table parameters, especially the intrinsic rate of increase $\left(r_{m}\right)$, are very important biological features for describing the population growth rate and are used to assess the potential effectiveness of natural enemies. These tables can describe duration and survival at each life stage. Daily fecundity data generated by these tables allow prediction of the population size and age structure of a natural enemy at any time (Southwood 1976; Southwood and Henderson, 2000).

Tommasini et al., (2004) carried out laboratory trials in order to determine biological traits and predation activity of four Orius species, viz. the palearctic Orius majusculus (Reuter), O. laevigatus and Oriusniger Wolff and the Nearctic $O$. insidiosus, using Ephestia kuehniella (Zeller) eggs and $F$. occidentalis adults as prey. Baniameri et al., (2005) too studied life table and age-dependent reproduction of $O$. niger on E. kuehniella eggs. Kemasa et al., (2008) study on biological life table of Orius minutus (L.) fed with Thrips palmi and eggs of Corcyra cephalonica.

Tiwari et al., (2017) conducted studies on the biology and predation efficiency of Eocanthecona furcellata (Wolff.) on different hosts viz., Maruca vitrata, Spodoptera litura, Spilarctia obliqua, Corcyra cephalonica under laboratory condition to find out its preferred host, with the intention that the same could be utilized for the mass rearing.
However, no information or published data on reproductive biology or life table is available for $O$. bifilarus. Therefore, the objective of the present study was to determine the life table parameters of the flower bug, O. bifilarus, when fed on its natural prey, Thrips palmi and fictitious host i.e. eggs of $C$. cephalonica at constant temperature as the temperature plays an important role in determining the growth rate of insects as insects are poikilothermic animals whose metabolism, rate and magnitude of growth, development and overall behavioral activities respond significantly to temperature change (Saxena and Murty, 2014).

\section{Materials and Methods}

\section{Rearing}

$O$. bifilarus used in the experiments were collected on flowers and apical bud of cucumber, Cucumis sativus (L.) in Himachal Pradesh $\left(31.1033^{\circ} \mathrm{N}, 77.1722^{\circ} \mathrm{E}\right)$, India. $O$. bifilarus was identified by using the key and single rearing method (Ghauri, 1972; Yasunaga, 1997a, 1997b, 1997c). The adults were paired up and released in plastic container $\left(10.5 \times 10.5 \times 10.5 \mathrm{~cm}^{3}\right)$ with a moistened filter paper placed at its bottom and covered with a muslin cloth. Bean pods were provided as egg laying substrate. Adult rearing was divided into two experimental units. In one experimental unit adult predators were provide with its natural host i.e. T. palmi (collected from cucumber) as its prey and in another rearing unit they were provided with its fictitious host i.e. eggs of C. cephalonicaas prey. Adult predators were provided with fresh prey after every 1-2 days. Pods containing eggs of the anthocorid bugs were collected daily or on alternate days depending on egg laying rhythm of the female and placed in separate container for hatching and emergence of nymphs. Subsequently, nymphs were shifted to vials and provided with 
respective prey for rearing them to adult stage. Emerged adults were sexed, paired and further utilized to multiply their numbers. Observations on reproductive biology were recorded by maintaining male and female in pairs from the raised culture in rearing chamber containing sufficient prey as food source and oviposition substrate. Each pair of bugs was transferred to a test tube of diameter $3 \mathrm{~cm}$ and length $15 \mathrm{~cm}$. Opening was covered by a muslin cloth to provide ventilation. 20 such pairs were kept for these studies in each experimental unit. The dead male was replaced by another male. Observations on attaining reproductive maturity, duration of pre-oviposition, oviposition, and postoviposition periods were recorded. Total number of eggs oviposited during survival of the female and hatchability was recorded. The bugs were daily provided with respective prey and bean pod as food and oviposition sites. Bean pods were checked daily for Orius eggs and were kept in test tubes of diameter $1.5 \mathrm{cmand}$ length $9 \mathrm{~cm}$ until hatching. After hatching II instars were sifted individually to another test tube provides with moistened filter paper and respective prey to avoid cannibalism. Survival of eggs was recorded after the hatching of all of the eggs. To prevent disturbance of nymphs, their survival and sex were recorded at the emerging of the adults.

\section{Fertility analysis}

Fertility table was developed by using developmental biology statistics as per Birch (1948) and elaborated by Howe (1953) and Carey (1993).Data recorded on mortality in immature stages, number of adults formed and proportion of females among them, female progeny laid by each female at specific pivotal age and percentage of alive females of specific age group were utilized for construction of life-tables. The main parameters in a life table are $\mathrm{x}$ (pivotal age), lx (proportion of females surviving to start of age interval $\mathrm{x}$ ) and $\mathrm{mx}$ (average number of female eggs laid by a female of age $x$ ). The most basic measure of reproduction is the average number of eggs laid by a female in the cohort in the interval $\mathrm{x}$ to $\mathrm{x}+1$ and is denoted by Mx. The fraction of these eggs that hatch represents the hatch schedule, hx 0). We followed the methods of Birch (1948), Howe (1953) and Carey (1993) for calculating life table parameters and reproductive parameters. Southwood (1976) gave a graphical method for the calculation of precise value of $r_{m}$. The arbitrary values of $r_{c}$ up to two decimal places were substituted in the formula $\Sigma l_{x} m_{x} e^{-r m(x+0.5)}$ until the two values were found one of which lie immediately above 1 and the other below 1 . These values were then plotted on the horizontal axis against their respective arbitrary values of $\mathrm{r}_{\mathrm{m}}$ on vertical axis. The points were joined to give a line which intersected a vertical line drawn from the desired value of $\Sigma 1_{x} m_{x} e^{-r m(x+0.5)}$ $=1$. The point of intersection gave the value of $\mathrm{r}_{\mathrm{m}}$ accurate to three decimal places. The intrinsic rate of increase can also be used to estimate the effect of mortality of each stage on the population growth rate, and this can subsequently be used to optimize mass rearing. Antilog of $r_{m}$ is known as finite rate of increase, which depicts the number of times the population increases per unit time in a generation. Net reproductive rate $\left(\mathrm{R}_{0}\right)$, intrinsic rate of increase $\left(r_{m}\right)$, finite rate of increase $(\lambda)$, intrinsic birth rate (b), intrinsic death rate (d), doubling time (DT) and mean generation time (T) were calculated using the formulae shown in Table 2.

\section{Results and Discussion}

The survival and fecundity rate are two important parameters which contribute towards population increase. Keeping this in view fertility tables of $O$. bifilarus were prepared after feeding their progeny on Corcyra eggs and T. palmi. 
In experimentally maintained pairs of $O$. bifilarus on Corcyra eggs and T. palmi, mating was often observed one day after adult emergence. When fed on Corcyra eggs, the pre-oviposition, oviposition and postoviposition periods were $4.3+0.78,14.2+$ 4.56 and $1.4+1.56$ days, while on thrips as prey, these were $4.3+0.70,16.4+7.12$ and $2.0+2.00$ days, respectively (Table 3 ). There was a non-significant difference on these attributes of reproduction between two tested prey.

The eggs were often laid singly by inserting ovipositor into the bean pod tissue. The number of egg laid per female per day ranged from $0-6$ on both hosts. The total eggs laid per female during its life span ranged from 20-65 (40.8) and 7-67 (42.1) and their survival was for 10-27 (19.8) and 13-35 (22.7) days on Corcyra eggs and T. palmi, respectively. The sex ratio was (female: male) 1: $1.3(57 \%$ female).

The survival from egg stage till attaining the adult stage on eggs of C. cephalonica was 78 per cent and the bug started egg laying at the pivotal age of 24 days (Table 1). The last reproducing female survived up to 31 days. The female progeny deposited by a female $\left(\mathrm{m}_{\mathrm{x}}\right)$ during its survival ranged from 0.06 to 2.22 and the maximum number of female progeny was produced on pivotal age of $32^{\text {nd }}$ day (Fig. 1a). The mean female progeny per female over the entire reproduction period (gross reproductive rate) was $23.26 \mathrm{The}$ net reproductive rate was $15.97 \mathrm{female}$ eggs/female. This bug had an approximate generation time $\left(\mathrm{T}_{\mathrm{c}}\right)$ of 32.09 days and true generation time $(\mathrm{T})$ of 31.38 days. Thus the bug would multiply 15.97 times in a single generation of about 32 days. Its capacity for natural increase $\left(r_{c}\right)$ was 0.086 , while the true intrinsic rate of increase $\left(\mathrm{r}_{\mathrm{m}}\right.$, determined graphically) was 0.088 . The species showed the infinite rate of increase $(\lambda)$ of 1.09 times/day under the existing conditions. Doubling time (DT) was 7.85 days and weekly multiplication rate was1.85 female eggs/female. The gross fecundity of the species on Corcyra eggs was 40.8 eggs with gross fertility rate of 33.25 eggs, while egg hatch was 81.5 per cent with net fertility of $29.79 \mathrm{eggs} / \mathrm{female}$. The female on average laid 1.65 eggs/day and amongst these fertile eggs were 1.35/female/day (Table 3).

The survival till attaining the adult stage on $T$. palmi was 76 per cent and female mortality was first observed at the pivotal age of 31 days, which increased slowly thereafter (Fig. 1b). The maximum longevity of ovipositing female was 35 days. A single female on an average produced 0.28 female progeny $\left(\mathrm{m}_{\mathrm{x}}\right)$ on the first day of oviposition, reaching a maximum of 2.22 on 7th day (Table 1). Population growth statistics reveal that the species had the gross reproduction rate (GRR) of 24 female eggs per female and the net reproduction rate $\left(R_{o}\right)$ of 14.62 female eggs per female. The population would thus multiply 14.62 times per generation. The approximate generation time $\left(\mathrm{T}_{\mathrm{c}}\right)$ was 32.5 and the innate capacity of natural increase $\left(r_{c}\right)$ was 0.083 . This arbitrary value of $r_{m}$ was used to determine the true intrinsic rate of increase $\left(\mathrm{r}_{\mathrm{m}}\right)$ graphically as 0.085 . The finite rate of increase $(\lambda)$ was 1.09 , while the true generation time $(\mathrm{T})$ and the time taken to double the population (DT) were 31.48 and 8.14 days, respectively. The gross fecundity of the bug was 42.1 eggs with gross fertility rate of 32.72 eggs and egg hatch of 78 per cent with net fertility of 26.85 eggs/female. The female on an average laid 1.48 eggs/day and amongst these fertile eggs were 1.15 (Table $3)$.

Average duration of three reproductive phases of $O$. bifilarus, viz. pre-oviposition, oviposition and post- oviposition period was 4.3, 14.2 and 1.4 days on C. cephalonica eggs 
and $4.1,16.4$ and 2.1 days on $T$. palmi, the difference being non-significant. However, for O. insidiosus, a much worked out species, lepidopteran eggs (E. kuehniella) increased longevity (individuals fed on the eggs of Heliothisvirescens lived 3 times longer than on thrips, Sericothripsvariabilis: Kiman and Yeargan, 1985) 44 days (Richards and Schmidt, 1996) and only 9 days on A. gossypii (Bush et al., 1993), 5 times more than that on nymphs of A.gossypii and 4 times more than that on thrips Caliothripsphaseoli (Mendis et al., 2002), reduced the pre-oviposition period (half than that on thrips: Mendes et al., 2002) and increased the oviposition period ( 5 times longer than that on nymphs of A. gossypii (Mendes et al., 2002).

The fecundity of $O$. bifilarus reared on Corcyra eggs and T. palmi did not differ significantly and was 41 (20-65) and 42.3 eggs/female, respectively, though the female survival was slightly longer (22.7 days) on thrips as compared to Corcyra eggs (19.8 days) and hence Corcyra eggs can effectively be used for mass rearing of $O$. bifilarus. However, the fecundity of $O$. insidiosus was directly affected by the quality of their diet. According to Mendes et al., (2002) females fed on theeggs of E. kuehniella laid about nine times more eggs (195.3 \pm 22.77 eggs) than those fed on $A$. gossypii (20.0 \pm 5.50 eggs/female) and three times more eggs than those fed on Caliothripsphaseoli $(70.0 \pm 7.48$ eggs/female).

High rates of egg laying by females fed on Lepidoptera eggs was also observed by Tommasini \& Nicoli (1993), who reported that females fed on the eggs of E. kuehniella laid about 2.5 times more eggs than females that preyed on thrips Frankliniella occidentalis. Similarly Bush et al., (1993) found that females fed on the eggs of Heliothis virescens laid five times more eggs than those that consumed A. gossypii. The results obtained in this study with regard to the different types of prey pointed out the nutritional superiority of Lepidoptera eggs as the prey of choice for development and reproduction of $O$. insidiosus; similar conclusion was drawn by Eubanks and Denno (2000), who stated that lepidopteran eggs were prey of high quality for many generalist predators, while aphids were relatively of low nutritional quality. Ferkovich and Shapiro (2004) found improved rearing and oviposition rate of $O$. insidiosus on an artificial diet supplemented with cells from an embryonic line, IPLB-(PiE) of Plodia interpunctella (Hubner) with increase in concentration of cells added to the diet and later in 2005, recorded that eggs production significantly increased only in a fraction of protein separated from the cell line having isoelectric point of $\mathrm{pH} 5$ and this fraction contained several Commassie blue-stained bands, but the exact nature of this fecundity factor was not known (Ferkovich and Shapiro, 2005).

Mean number of eggs laid per oviposition day by $O$. bifilarus reared on $C$. cephalonica eggs and thrips was 2.9 and 2.6, respectively. Blaeser et al., (2004) showed that mean number of eggs laid was significantly different among the three species of Orius; $O$. majuscules laid 0.8 eggs/day, while $O$. albidipennis and $O$. sauteri laid 1.1 and 2.2 eggs/day, respectively, when fed on $F$. occidentalis.

Fertility table summarizes the information on biological performance of a species. It takes into cognizance the survival value and fecundity rate for determining net reproductive rate $\left(\mathrm{R}_{\mathrm{o}}\right)$ and innate capacity to increase $\left(r_{c}\right)$. The latter is exploited to determine the intrinsic rate of the natural increase of the species $\left(r_{m}\right)$ and true generation time $(\mathrm{T})$. Intrinsic rate of natural increase $\left(\mathrm{r}_{\mathrm{m}}\right)$ is a measure of biotic potential of the species. 
Table.1 Life table and age-dependent reproduction of Orius bifilarus on Corcyra cephalonica eggs and on thrips $x=$ age of female in days; $l x=$ survival of female until $x$; $m x=$ number of female offspring produced at age $x ; M x=$ total number of offspring (=number of eggs) produced at age $x$, $h x=$ hatch rate of eggs

\begin{tabular}{|c|c|c|c|c|c|c|c|c|c|}
\hline \multicolumn{5}{|c|}{$\begin{array}{c}\text { Fertility table parameter on Corcyra } \\
\text { cephalonicaeggs }\end{array}$} & \multicolumn{5}{|c|}{ Fertility table parameter on Thrips spp. } \\
\hline$(\mathbf{x})$ & $\left(1_{\mathrm{X}}\right)$ & $\left(m_{x}\right)$ & $\left(M_{x}\right)$ & $\left(h_{x}\right)$ & (x) & $\left(1_{\mathrm{x}}\right)$ & $\left(\mathrm{m}_{\mathrm{x}}\right)$ & $\left(\mathrm{M}_{\mathrm{x}}\right)$ & $\left(h_{x}\right)$ \\
\hline $0-5$ & 0.90 & 0 & 0 & 0 & $0-5$ & 0.87 & 0 & 0 & 0 \\
\hline 6-23 & 0.78 & 0 & 0 & 0 & $6-23$ & 0.76 & 0 & 0 & 0 \\
\hline 24 & 0.78 & 0.23 & 0.4 & 1 & 24 & 0.76 & 0.28 & 0.5 & 1 \\
\hline 25 & 0.78 & 0.74 & 1.3 & 0.92 & 25 & 0.76 & 0.51 & 0.9 & 0.78 \\
\hline 26 & 0.78 & 1.08 & 1.9 & 0.94 & 26 & 0.76 & 0.68 & 1.2 & 0.83 \\
\hline 27 & 0.78 & 1.25 & 2.2 & 0.95 & 27 & 0.76 & 1.25 & 2.2 & 0.64 \\
\hline 28 & 0.78 & 1.54 & 2.7 & 0.85 & 28 & 0.76 & 1.99 & 3.5 & 0.8 \\
\hline 29 & 0.78 & 1.77 & 3.1 & 0.78 & 29 & 0.76 & 1.99 & 3.5 & 0.8 \\
\hline 30 & 0.78 & 1.94 & 3.4 & 0.8 & 30 & 0.76 & 2.22 & 3.9 & 0.69 \\
\hline 31 & 0.78 & 1.88 & 3.3 & 0.74 & 31 & 0.68 & 1.82 & 3.2 & 0.69 \\
\hline 32 & 0.78 & 2.22 & 3.9 & 0.72 & 32 & 0.68 & 1.71 & 3 & 0.87 \\
\hline 33 & 0.78 & 1.82 & 3.2 & 0.8 & 33 & 0.61 & 1.48 & 2.6 & 0.81 \\
\hline 34 & 0.78 & 1.71 & 3 & 0.86 & 34 & 0.54 & 1.42 & 2.5 & 0.8 \\
\hline 35 & 0.78 & 1.31 & 2.3 & 0.82 & 35 & 0.55 & 1.19 & 2.1 & 0.9 \\
\hline 36 & 0.55 & 1.08 & 1.9 & 0.83 & 36 & 0.49 & 1.08 & 1.9 & 0.79 \\
\hline 37 & 0.39 & 0.91 & 1.6 & 0.83 & 37 & 0.44 & 0.91 & 1.6 & 0.75 \\
\hline 38 & 0.39 & 0.97 & 1.7 & 0.85 & 38 & 0.44 & 0.97 & 1.7 & 0.71 \\
\hline 39 & 0.39 & 0.80 & 1.4 & 0.8 & 39 & 0.53 & 0.68 & 1.2 & 0.92 \\
\hline 40 & 0.39 & 0.74 & 1.3 & 0.72 & 40 & 0.53 & 0.74 & 1.3 & 0.69 \\
\hline 41 & 0.39 & 0.46 & 0.8 & 0.77 & 41 & 0.46 & 0.63 & 1.1 & 0.91 \\
\hline 42 & 0.39 & 0.23 & 0.4 & 0.93 & 42 & 0.46 & 0.57 & 1 & 0.6 \\
\hline 43 & 0.23 & 0.11 & 0.2 & 1 & 43 & 0.30 & 0.29 & 0.5 & 0.8 \\
\hline 44 & 0.23 & 0.17 & 0.3 & 0.83 & 44 & 0.30 & 0.39 & 0.7 & 0.86 \\
\hline 45 & 0.23 & 0.17 & 0.3 & 0.55 & 45 & 0.30 & 0.23 & 0.4 & 0.75 \\
\hline 46 & 0.23 & 0.06 & 0.1 & 0.58 & 46 & 0.23 & 0.17 & 0.3 & 1 \\
\hline 47 & 0.16 & 0.00 & 0 & 1 & 47 & 0.15 & 0.29 & 0.5 & 1 \\
\hline 48 & 0.16 & 0.06 & 0.1 & 0 & 48 & 0.15 & 0.23 & 0.4 & 0.5 \\
\hline 49 & 0.08 & 0 & 0 & 1 & 49 & 0.15 & 0.06 & 0.1 & 0 \\
\hline 50 & 0.08 & 0 & 0 & 0 & 50 & 0.15 & 0.11 & 0.2 & 0.5 \\
\hline 51 & 0.08 & 0 & 0 & 0 & 51 & 0.15 & 0.06 & 0.1 & 1 \\
\hline 52 & 0.08 & 0 & 0 & 0 & 52 & 0.15 & 0 & 0 & 0 \\
\hline 53 & 0.08 & 0 & 0 & 0 & 53 & 0.08 & 0 & 0 & 0 \\
\hline 54 & 0 & 0 & 0 & 0 & 54 & 0.08 & 0 & 0 & 0 \\
\hline & & & & & 55 & 0.08 & 0 & 0 & 0 \\
\hline & & & & & 56 & 0.08 & 0 & 0 & 0 \\
\hline & & & & & 57 & 0.08 & 0 & 0 & 0 \\
\hline & & & & & 58 & 0 & 0 & 0 & 0 \\
\hline
\end{tabular}


Table.2 Description, formula, symbol, values and units for population parameters of Orius bifilarus on two different hosts

\begin{tabular}{|c|c|c|c|}
\hline Parameter: Formula & & $\begin{array}{c}\text { Corcyra } \\
\text { cephalonica eggs }\end{array}$ & Thrips spp. \\
\hline Gross reproductive rate: $\left(\sum\left(\mathbf{m}_{\mathbf{x}}\right)\right)$ & $=$ & 23.26 & 24.0 \\
\hline $\begin{array}{l}\text { Net Reproductive rate (female egg/female) ( } \\
\left.{ }_{0}\right):\left(\sum\left(\mathbf{l}_{\mathbf{x}} \mathbf{m}_{\mathbf{x}}\right)\right)\end{array}$ & $=$ & 15.97 & 14.62 \\
\hline Approximate Generation Time $\left(\mathbf{T}_{\mathrm{c}}\right):\left(\sum\left(\mathrm{xl}_{\mathrm{x}} \mathbf{m}_{\mathrm{x}}\right) / \mathbf{R}_{\mathrm{o}}\right)$ & $=$ & 32.09 & 32.50 \\
\hline The Innate Capacity for increase $\left(r_{c}\right):\left(\log _{e} R_{0} / T\right)$ & $=$ & 0.086 & 0.083 \\
\hline $\begin{array}{l}\text { Intrinsic rate of } \\
(\text { daughter/female/day })\left(r_{m}\right)\end{array}$ natural increase & $=$ & 0.088 & 0.085 \\
\hline True Generation Time $(T):\left(\log _{\mathrm{e}} \mathbf{R}_{\mathrm{o}} / \mathrm{r}_{\mathrm{m}}\right)$ & $=$ & 31.38 & 31.48 \\
\hline Finite rate of increase $(\lambda)$ : $\left(\right.$ Antilog $\left.{ }_{e} r_{m}\right)$ & $=$ & 1.09 & 1.09 \\
\hline Doubling Time (DT): $\left(\log _{\mathrm{e}} 2 / \mathrm{r}_{\mathrm{m}}\right)$ & $=$ & 7.85 & 8.14 \\
\hline Weekly multiplication rate: $\left({ }_{e} 7 r_{m}\right)$ & $=$ & 1.85 & 1.82 \\
\hline Intrinsic Birth rate $(b):\left(\sum e^{-r m(x+0.5)} I_{x}\right)$ & $=$ & 0.81 & 0.84 \\
\hline Intrinsic Death Rate $(d):\left(b-r_{m}\right)$ & $=$ & 0.72 & 0.75 \\
\hline Gross fecundity: $\left(\sum\left(\mathbf{M}_{\mathbf{x}}\right)\right)$ & $=$ & 40.80 & 42.1 \\
\hline Gross fertility rate: $\left(h_{x} M_{x}\right)$ & $=$ & 33.25 & 32.72 \\
\hline Gross hatch rate: $\left(\sum \mathbf{h}_{\mathbf{x}} \mathbf{M}_{\mathbf{x}} / \sum \mathbf{M}_{\mathbf{x}}\right)$ & $=$ & 0.815 & 0.78 \\
\hline Net fertility rate: $\left(\sum \mathbf{L}_{\mathbf{x}} \mathbf{h}_{\mathbf{x}} \mathbf{M}_{\mathbf{x}}\right)$ & $=$ & 29.79 & 26.85 \\
\hline Eggs /female /day: $\left(\sum \mathbf{L}_{\mathbf{x}} \mathbf{M}_{\mathbf{x}} / \sum \mathbf{L}_{\mathbf{x}}\right)$ & $=$ & 1.65 & 1.48 \\
\hline Fertile eggs/ female/day: $\left(\sum \mathbf{L}_{\mathbf{x}} \mathbf{h}_{\mathbf{x}} \mathbf{M}_{\mathbf{x}} / \sum \mathbf{L}_{\mathbf{x}}\right)$ & $=$ & 1.35 & 1.15 \\
\hline Mean age gross fecundity (days): $\left(\sum_{x} M_{x} / \sum M_{x}\right)$ & $=$ & 32.52 & 33.40 \\
\hline Mean age gross fertility (days): $\left(\sum \mathbf{x h}_{\mathrm{x}} \mathbf{M}_{\mathrm{x}} / \sum \mathbf{h}_{\mathbf{x}} \mathbf{M}_{\mathrm{x}}\right)$ & $=$ & 32.32 & 33.40 \\
\hline Mean age net fecundity: $\left(\sum \mathbf{x} \mathbf{L}_{\mathbf{x}} \mathbf{M}_{\mathbf{x}} / \sum \mathbf{L}_{\mathbf{x}} \mathbf{M}_{\mathbf{x}}\right)$ & $=$ & 31.65 & 32.12 \\
\hline Mean age net fertility: $\left(\sum x L_{x} h_{x} M_{x} / L_{x} h_{x} M_{x}\right)$ & $=$ & 31.50 & 32.16 \\
\hline Mean age hatch: $\left(\sum \mathrm{xh}_{\mathrm{x}} / \sum \mathbf{h}_{\mathrm{x}}\right)$ & $=$ & 35.86 & 37.00 \\
\hline
\end{tabular}

Table.3 Reproductive phases of Orius bifilarus on two hosts

\begin{tabular}{|l|c|c|c|c|}
\hline & \multicolumn{2}{|c|}{ Corcyra eggs } & \multicolumn{2}{c|}{ Thrips } \\
\hline Reproductive phases & Mean \pm SD & Range & Mean \pm SD & Range \\
\hline $\begin{array}{l}\text { Pre oviposition period } \\
\text { (days) }\end{array}$ & $4.3 \pm 0.78$ & $3-6$ & $4.1 \pm 0.70$ & $3-5$ \\
\hline Oviposition period (days) & $14.2 \pm 4.56$ & $7-24$ & $16.4 \pm 7.12$ & $4-28$ \\
\hline $\begin{array}{l}\text { Post oviposition period } \\
\text { (days) }\end{array}$ & $1.4 \pm 1.56$ & $0-5$ & $2.0 \pm 2.00$ & $0-7$ \\
\hline Adult survival (days) & $19.8 \pm 6.34$ & $10-27$ & $22.7 \pm 6.56$ & $13-35$ \\
\hline
\end{tabular}




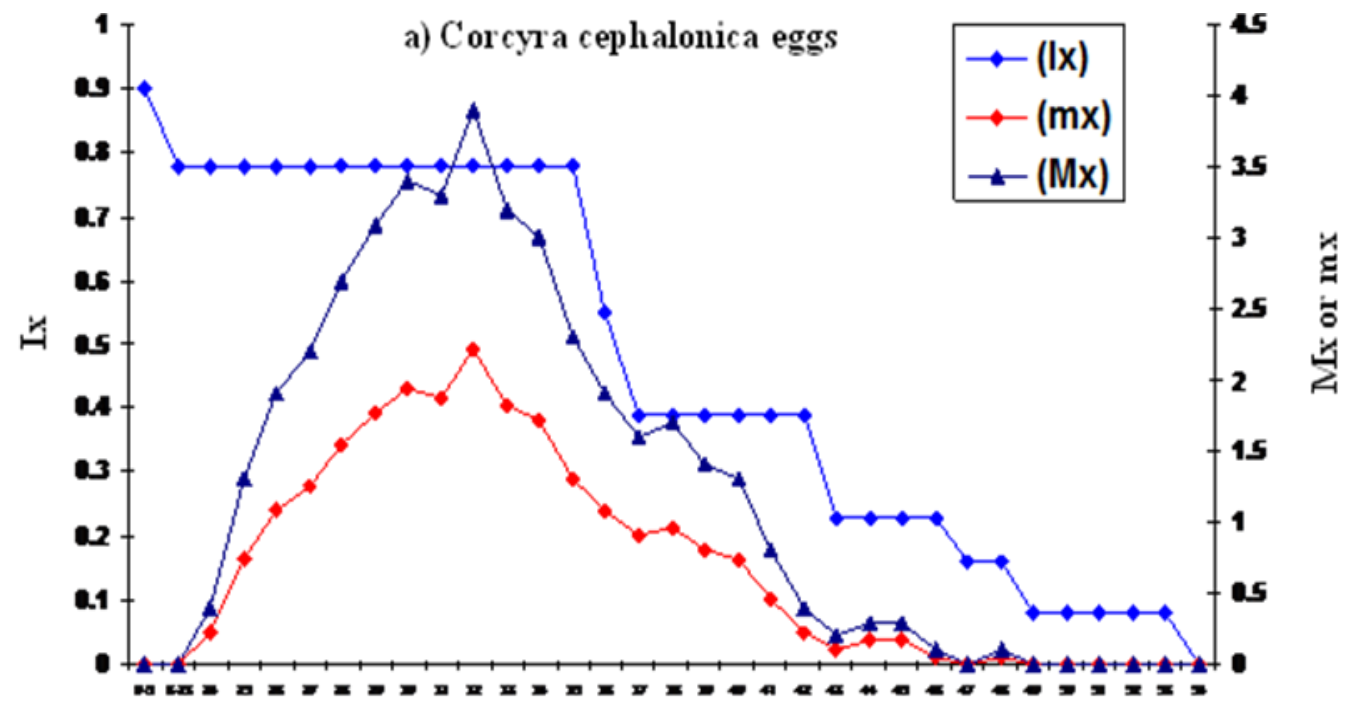

$\mathrm{X}$ (days)

b) Thrips spp.

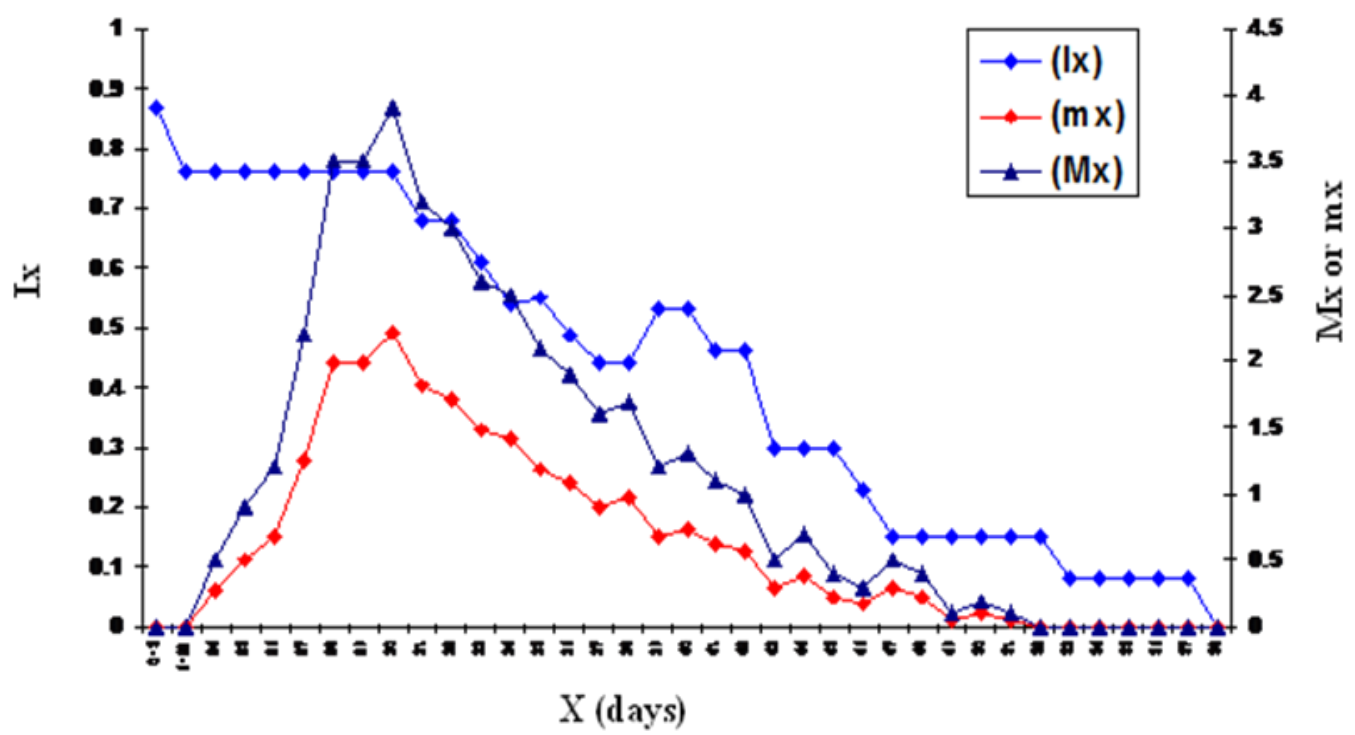

Fig. 1. Reproduction and survival curves of Orius bifilarus on eggs of $\mathrm{C}$. cepholonica (a) and Thrips spp. (b) $\mathrm{l} x=$ survival of females until age $\mathrm{x}$; $\mathrm{mx}=$ number of female off spring produced at age $x$; andMx total number of offspring (number of eggs) produced at age $x$ (days). 
Its calculation is based on innate capacity to increase $\left(r_{c}\right)$ and the later is determined by dividing net reproductive rate on natural log scale with the approximate generation time. The intrinsic rate of increase is a basic parameter which an ecologist may wish to establish for an insect population. Birch (1948) defined the intrinsic rate of increase as the rate of increase per head under specified physical conditions, in an unlimited environment where the effect of increases in density do not need to be considered. Lewontin (1965) indicated that studies on the effect of changing various aspects of the life cycle on the intrinsic rate of increase of a species were important. He considered even the effect of small changes in such life cyclephenomena as fecundity, longevity, length of developmental period etc., on the rate of increase. Jervis and Copland (1996) reviewed the use of life table analysis both by ecologists and by biological control workers. They indicated that, in a biological control programme, when faced with a choice of candidate parasitoid species, in the absence of other criteria the selection would be for the species with the greatest value for the intrinsic rate of natural increase. The advantage of using the intrinsic rate of increase is that it integrates the effects of mortality and fertility factors into a single value. Species having high $r_{m}$ values usually have high net reproductive rate and / or lesser generation time. Thus, instead of comparing several life history characteristics (i.e. development rate, longevity, fertility, mortality, sex ratio) among the population, a single comparison can be applied (Havelka and Zemek, 1999). The intrinsic rate of increase can also be used to estimate the effect of mortality of each stage on the population growth rate, and this can subsequently be used to optimize mass rearing. Antilog of $r_{m}$ is known as finite rate of increase, which depicts the number of times the population increases per unit time in a generation.
The net reproductive rate which is the measure of number of females produced per female in each generation, was almost same on thrips (collected from beans and cucurbits) and C. cephalonica eggs (14.62 and 15.97female progeny/female, respectively) for O. bifilarus

On the basis of literature, Sabelis and Van Rijn (1997) stated that the $\mathrm{r}_{\mathrm{m}}$ value for $O$. niger was the lowest among all Orius species studied using E. kuehniella as food source, while Tommasini et al., (2004) even found a negative value (-0.003). However, Baniameri et al., (2005) obtained high $\mathrm{r}_{\mathrm{m}}$ for this species reared at 26,29 and $32{ }^{\circ} \mathrm{C}(0.113,0.127$ and 0.157 daughters/female/day, respectively) on $E$. kuehniella eggs. The value of $\mathrm{r}_{\mathrm{m}}$ for $O$. bifilarus was 0.0883 and 0.0875 female progeny/female/day on Corcyra eggs and thrips, respectively, and the finite rate of increase $(\lambda)$ as 1.092 and1.089. The $r_{m}$ value for $A$. dividens and $B$. pallescens was 0.069 and 0.0787 female progeny/female/day with $\lambda$ 1.071 and 1.082 females/female/day on Corcyra eggs.

The value of fertility parameters may vary from species to species and within species when fed upon different hosts and even when reared in different environmental conditions. Tommasini et al., (2004) worked out the life table of four Orius species, viz. $O$. insidiousus, O. laevigatus, O. majuscules and $O$. niger on eggs of E. kuehniella and thrips $F$. occidentalis at $26^{\circ} \mathrm{C}$ and found $\mathrm{r}_{\mathrm{m}}$ value to be $0.101,0.068,0.080$ and -0.003 on $E$. kuehniella and 0.116, 0.94, 0.097 and 0.035 on $F$. occidentalis, respectively, for these species and concluded that $F$. occidentalis was the best for multiplication of first three species. Kakimoto et al., (2004) found that on the eggs of E. kuehniella at 17, 20, 23 and $26^{\circ} \mathrm{C}$, the mean generation time of three species was nearly the same at all the temperatures but the net reproductive rate of 
$O$. minutus was higher than that of other two species, i.e. O. strigicollis and $O$. sauterii, and that of $O$. strigicollis was the highest among the three species at $29^{\circ} \mathrm{C}$. Although the intrinsic rate of natural increase did not differ among the three species, the rate for $O$. strigicollis was far higher than that for other two species at $29^{\circ} \mathrm{C}$, thus interspecific differences in the reproductive potential of 3 species tend to become larger as the temperature increases, and $O$. strigicollis was advantageous over a wider temperature range than the other two species. According to Cocuzza et al., (1997), the $\mathrm{r}_{\mathrm{m}}$ value increased with temperature $\left(0.121\right.$ at $25^{\circ}$ and 0.202 at $35^{\circ} \mathrm{C}$ ), whereas for $O$. laevigatus it peaked at $25^{\circ} \mathrm{C}(0.0105)$ but decreased at $35^{\circ} \mathrm{C}$. Kemasa et al., (2008) made biological study on Orius minutus (L.) on Thrips spp., egg of $C$. cephalonica and Tetranychus spp. and concluded that egg of $C$. cephalonica followed by Thrips spp. suited for massrearing process of Orius sp. as the capacity for increase $\left(r_{c}\right.$ and 0.365 and 0.086 and the finite rate of increase $(\lambda)=1.44$ and 1.0898 and the cohort generation time $\left(\mathrm{T}_{\mathrm{c}}\right)=13.4386$ and 16.7598 days when fed with Thrips spp. and $C$. cephalonica eggs, respectively. From these statistics, it can be concluded that performance of different Orius spp. is affected by environmental conditions.

In conclusion, results of the present study suggest that the predatory bug $O$. bifilarus can easily be reared on fictitious diet of $C$. cephalonica eggs. There is no significant difference between life table parameters when reared on fictitious host and natural host and is therefore a possible candidate for mass releases for biological control of various thrips species. Because of its adaptation to varying climates in its area of origin, it is hoped that the present study can elucidate some of the factors responsible for efficacy of $O$. bifilarus to control different soft bodied insect pests on greenhouse plants in India.

\section{Acknowledgment}

The authors expresses their gratitude to Vice Chancellor of Dr Y.S. Parmar University of Horticulture and Forestry, Solan (H.P)-India, for providing necessary facilities in Field station and Entomology and Apiculture research Laboratory.

\section{References}

Ananthakrishnan, T. N. and Sureshkumar N. 1985. Anthocorids as efficient biocontrol agents of thrips. Current Science 54 (19): 987-990.

Andrewartha, H. G. and Birch, L. C. 1954. The distribution and abundance of animals. 782 p. University of Chicago Press, Chicago.

Awadallah, K. T., El-Dakroury, M. S. I., Elheneid, A. M. and Abbas, M. S. T. 1977. A study of the efficiency of Orius albidipennis Reut. (Hemiptera: Anthocoriae) when fed on either eggs or newly hatched larvae of Heliothis armigera Hb. (Lepidoptera: Noctuidae). Agric Res. Rev 55(1): 79-85.

Baniameri, V., Nejadian, E. S. and Mohaghegh, J. 2005. Life table and agedependent reproduction of the predatory bug Orius niger Wolff (Heteroptera : Anthocoridae) at three constant temperature : a demographic analysis. Applied Entomology and Zoology 40(4): 545-550.

Birch, S. 1948. The intrinsic rate of natural increase in insect population. Journal of AnimalEcology17: 15-26.

Blaeser, P., Sengonca, C. and Zegula, T. 2004. The potential use of different predatory bug species in the biological control of Frankliniella occidentalis (Pergande) (Thysanoptera: Thripidae). Entomologia Experimentalis et Applicata 85(3): 189-198. 
Bush, L., Kring, T. J. and Rubserson, J. R. 1993. Suitability of green bugs, cotton aphids, and Heliothis virescens eggs for the development and reproduction of Orius insidiosus. Entomologia Experimentalis et Applicata 67: 217222.

Carey, J. R. 1993. Applied demography for biologists with special emphasis on insects. 206 pp. Oxford University Press, New York.

Carvalho, L. M., Bueno, V. H. P. and Castane, C. 2011. Olfactory response towards its prey Frankliniella occidentalis of wild and laboratoryreared Orius insidiosus and Orius laevigatus. Journal of Applied Entomology 135: 177-183.

Chow, A., Chau, A. and Heinz, K. M. 2010.Compatibility of Amblyseius (Typhlodromips) swirskii (AthiasHenriot) (Acari: Phytoseiidae) and Orius insidiosus (Hemiptera: Anthocoridae) for biological control of Frankliniella occidentalis (Thysanoptera: Thripidae) on roses. Biological Control 53(2): 188-196.

Cocuzza, G. E., Clercq, P. D., Lizzio, S., Van de Veire, M., Tirry, L., Degheele, D. and Vacante, V. 1997. Life tables and predation activity of Orius laevigatus and $O$. albidipennis at three constant temperature.

Entomologia Experimentalis et Applicata85: 189198.

Dogramaci, M., Arthurs, S. P., Chen, J. J., McKenzie, C., Irrizary, F. and Osborne, L. 2011.Management of chillithrips Scirtothrips dorsalis (Thysanoptera: Thripidae) on peppers by Amblyseius swirskii (Acari: Phytoseiidae) and Orius insidiosus (Hemiptera: Anthocoridae). Biological Control59: 340-347.

Eubanks, M. D. and Denno, R. F. 2000. Health food versus fast food: the effects of prey quality and mobility on prey selection by a generalist predator and indirect interactions among prey species. Ecological Entomology25: 140146

Ferkovich, S. M. and Shapiro, J. P. 2005. Enhanced oviposition in the insidiosus flower bug, Orius insidiosus (Hemiptera: Anthocoridae) with a partially purified nutritional factor from prey eggs. Florida Entomologist 88(3): 253-257

Ghauri, M. S. K. 1972. The identity of Orius tantillus (Motschulsky) and notes on other oriental Anthocoridae (Hemiptera, Heteroptera). Journal of Natural History6: 409-421.

Havelka, D. J. and Zemek, R. 1999. Life table parameters and oviposition dynamics of various population of the predacious gall-midge Aphidoletes aphidimyz. Entomologia Experimentalis et Applicata 91: 481-484.

Hemerik, L. and Yano, E. 2011. Scaling up from individual behavior of Orius sauteri foraging on Thrips palmi to its daily functional response. Population Ecology 53: 563-569.

Howe, R. W. 1953. The rapid determination of intrinsic rate increase of an insect population. Annals of Applied Biology40: 134-155.

Jervis, M. A. and Copland, M. J. W. 1996. The life cycle. (in) Insect Natural Enemies. Practical Approaches to Their Study and Evolution, pp 63-161. Jervis M and Kidd N. (eds). Chapman \& Hall, London.

Kakimoto, K., Urano, S., Noda, T., Matuo, K., Sakamaki, Y., Tsuda, K. and Kusigemati, K. 2004. Comparison of the reproductive potential of three Orius species, O. strigicollis, O. sauteri and O. minutus (Heteroptera: Anthcoridae) using eggs of the Mediterranean flour moth as a food source. Applied 
Entomololgy and Zoology40(2): 247255.

Kawai, A. 1995. Control of Thrips palmi Karny (Thysanoptera: Thripidae) by Orius spp. (Heteroptera: Anthocoridae) on green house egg plant. Applied Entomoogyand Zoology 30: 1-7.

Kemasa, O., Kaewpradit, A. and Suasa-ard, W. 2008. Mass-rearing techniques of predatory anthocorid, Orius minutus (L.) (Hemiptera: Anthocoridae). Proceeding of the 46th Kasetsart University Annual Conference, pp 4651, 29 Jan-1 Feb, 2008, Kasetsart.

Kiman, Z. B. and Yeargan, K. V. 1985. Development and reproduction of the predator Orius insidiosus (Hemiptera, Anthocoridae) reared on diets of selected plant material and arthropod prey. Annals of the Entomological Society of America 78(4): 464-467.

Lewontin, R.C. 1965. Selection of colonizing ability. In: Baker, H.G. and G.L. Stebbins (eds.), The Genetics of Colonizing Species, Academic Press, New York and London, pp. 77-94.

Mendes, S. M., Bueno, V. H. P., Argolo, V. M. and Silveira, L. C. P. 2002. Type of prey influences biology and consumption rate of Orius insidiosus (Say) (Hemiptera, Anthocoridae). Revista Brasileira de Entomologia 46(1): 99-103.

Nasser, M. and Abdurahiman, U. C. 2004. Anthocorid predators and their biocontrol potential. (in) Indian Insect Predators in Biological Control, pp 91114. Sahayaraj K. (Ed). Daya Publishing House, Delhi.

Osekre, F. A., Wrigh, D. L., Morois, J. J. and Mailhot, D. J. 2008. Predator-prey interactions between Orius insidiosus (Heteroptera: Anthocoridae) and Frankliniella tritici (Thysanoptera: Thripidae) in cotton blooms. The Journal of Cotton Science 12:195-201.
Rajasekhara, K. and Chatterji, S. 1970. Biology of Orius indicus (Hemiptera: Anthocoridae), a predator of Taeniothrips nigricornis (Thysanoptera). Annals of Entomological Society of America 63: 364-367.

Sabelis, M. W. and Van Rijn, P. C. J. 1997. Predation by insect mites. (in) Thrips as crop pests, pp 259-354. Lewis T. (Ed). CABI, London

Sakimura, K. 1963.Frankliniella fusca and additional vector forthe tomato spotted wilt virus, with notes on Thrips tabaci, another vector. Phytopathology, 53: $412-415$

Saxena, S. and Murty, N. S. 2014. Weather based model development for outbreak of mustard aphid (l.erysimi.,kalt) using artificial neural network. The Ecoscan. 8(1\&2): 47-52.

Shirk, P. D., Shapiro, J. P., Reitz, S. R., Thomas, J. M. G., Koenig, R. L., HayRoe, M. M. and Buss, L. J. 2012. Predator-prey relationships on Apiaceae at an organic farm. Environmental Entomology41:487-496.

Southwood, R. and Henderson, P.A. 2000. Ecological methods. $3^{\text {rd }}$ ed. Oxford: Blackwell Science.

Southwood, T. R. E. 1976. Ecological Methods with particular reference to the study of insect populations, $391 \mathrm{p}$, Mathuen and Company, Ltd., London.

Stuart, R., Gao, Y. and Lei, Z. 2011. Thrips: pests of concern to China and the United States. Agric. Sci. China 10: 867-892.

Tiwari, S., Maurya, R. P. and Pande, A. K. 2017. Effect of different insect hosts in biology and predation efficiency of Eocanthecona furcellata (Wolff.) (Hemiptera: Pentatomidae). The Bioscan12(1): 193-197, 201

Tommasini, M. G. and Nicoli, G. 1993. Adult activity of four Orius species reared on 
two preys. IOBC/wprs Bulletin16(2): 281-184

Tommasini, M. G., Van Lenteren, J. C. and Burgio, G. 2004. Biological traits and predation capacity of four Orius species on two prey species. Bulletin of Insectology 57(2): 79-93.

Wang, S., Michaud, J.P., Xiao-Ling, T. and Zhang, F. 2014. Comparative suitability of aphids, thrips and mites as prey for the flower bug Orius sauteri (Hemiptera: Anthocoridae). Eur. $J$. Entomol.111(2): 221-226.

$\mathrm{Xu}, \mathrm{X} . \mathrm{N}$. and Enkegaard, A. 2009. Prey Preference of Orius sauteri between Western flower thrips and spider mites.
Entomologia Experimentalis et Applicata 132(1): 93-98.

Yasunaga, T. 1997a. The flower bug Genus Orius Wolff (Heteroptera: Anthocoridae) from Japan and Taiwan, Part I. Applied Entomology and Zoology 32(2): 355-364.

Yasunaga, T. 1997b. The flower bug Genus Orius Wolff (Heteroptera: Anthocoridae) from Japan and Taiwan, Part II. Applied Entomology and Zoology 32(2): 379-386.

Yasunaga, T. 1997c. The flower bug Genus Orius Wolff (Heteroptera: Anthocoridae) from Japan and Taiwan, Part III. Applied Entomology and Zoology 32(2): 387-394.

\section{How to cite this article:}

Nisha Devi, P.R. Gupta, K.C. Sharma, P.L. Sharma and Negi, B.R. 2018. Fertility Table Parameters of Predatory Bug Orius bifilarus Ghauri (Hemiptera: Anthocoridae) Preying upon Thrips palmi and eggs of Corcyra cepholinica. Int.J.Curr.Microbiol.App.Sci. 7(03): 2574-2586. doi: https://doi.org/10.20546/ijcmas.2018.703.298 